\title{
Pyruvate Dehydrogenase Complex Activity in Normal and Deficient Fibroblasts
}

\author{
Kwan-Fu Rex Sheu, Chit-Whei C. Hu, and Merton F. Utter, Department of \\ Biochemistry, Case Western Reserve University, School of Medicine, \\ Cleveland, Ohio 44106
}

A B S T RACT Pyruvate dehydrogenase complex (PDC) activity in human skin fibroblasts appears to be regulated by a phosphorylation-dephosphorylation mechanism, as is the case with other animal cells. The enzyme can be activated by pretreating the cells with dichloroacetate (DCA), an inhibitor of pyruvate dehydrogenase kinase, before they are disrupted for measurement of PDC activity. With such treatment, the activity reaches $5-6 \mathrm{nmol} / \mathrm{min}$ per $\mathrm{mg}$ of protein at $37^{\circ} \mathrm{C}$ with fibroblasts from infants. Such values represent an activation of about 5-20-fold over those observed with untreated cells. That this assay, based on $\left[1-{ }^{14} \mathrm{C}\right]$ pyruvate decarboxylation, represents a valid measurement of the overall PDC reaction is shown by the dependence of ${ }^{14} \mathrm{CO}_{2}$ production on the presence of thiamin-PP, coenzyme A (CoA), $\mathrm{Mg}^{++}$, and $\mathrm{NAD}^{+}$. Also, it has been shown that acetyl-CoA and ${ }^{14} \mathrm{CO}_{2}$ are formed in a $1: 1$ ratio. A similar degree of activation of PDC can also be achieved by adding purified pyruvate dehydrogenase phosphatase and high concentrations of $\mathrm{Mg}^{++}$and $\mathrm{Ca}^{++}$, or in some cases by adding the metal ions alone to the cell homogenate after disruption. These results strongly suggest that activation is due to dephosphorylation. Addition of $\mathrm{NaF}$, which inhibits dephosphorylation, leads to almost complete loss of PDC activity.

Assays of completely activated PDC were performed on two cell lines originating from patients reported to be deficient in this enzyme (Blass, J. P., J. Avigan, and B. W. Ublendorf. 1970. J. Clin. Invest. 49: 423-432; Blass, J. P., J. D. Schuman, D. S. Young, and E. Ham. 1972.J. Clin. Invest. 51: 1545-1551). Even after activation with DCA, fibroblasts from the patients showed values of only 0.1 and $0.3 \mathrm{nmol} / \mathrm{min}$ per $\mathrm{mg}$ of protein. A familial study of one of these patients showed that

A preliminary account of this work was presented in 1980 . In Enzyme Therapy in Genetic Disease. R. J. Desnick, editor. Alan R. Liss, Inc., New York. 289-304.

Dr. Sheu and Ms. Hu wish to dedicate this work to the late Dr. Merton F. Utter.

Received for publication 13 November 1980 and in revised form 12 January 1981. both parents exhibited activity in fully activated cells about half that of normal values, whereas cells from a sibling appeared normal. These results demonstrate the inheritance nature of PDC deficiency, and that the present assay is sufficient to detect the heterozygous carriers of the deficiency. Application of the same procedures to fibroblasts obtained from 16 individuals who were believed to have normal PDC activities showed a range from about $2-2.5 \mathrm{nmol} / \mathrm{min}$ per $\mathrm{mg}$ protein for adults to $5-6 \mathrm{nmol} / \mathrm{min}$ per $\mathrm{mg}$ protein for cells from infants.

\section{INTRODUCTION}

Pyruvate dehydrogenase complex (PDC) ${ }^{1}$ catalyzes the oxidative decarboxylation of pyruvate:

Pyruvate + coenzyme A (CoA)

$$
+\mathrm{NAD}^{+} \frac{\mathrm{Mg}^{++}, \text {thiamin pyrophosphate (TPP) }}{\text { Acetyl-CoA }+\mathrm{NADH}+\mathrm{CO}_{2} .}
$$

The mammalian multienzyme complex can be resolved into three catalytic components and two regulatory enzymes $(1,2)$. The three catalytic components are pyruvate dehydrogenase (PDH) (EC 1.2.4.1), dihydrolipoyl transacetylase (EC 2.3.1.12), and dihydrolipoyl dehydrogenase (EC 1.6.4.3), which act sequentially in that order. The two regulatory enzymes are pyruvate dehydrogenase kinase $\left(\mathrm{PDH}_{\mathrm{a}}\right.$ kinase) (EC 2.7.1.99), which catalyzes the Mg-ATP-dependent phosphorylation of PDH with concomitant inactivation, and pyruvate dehydrogenase phosphate phosphatase $\mathrm{PDH}_{\mathrm{b}}$ phosphatase) (EC 3.1.3.43) which dephosphorylates $\mathrm{PDH}_{\mathrm{b}}$ with concomitant activation of the enzyme (3).

\footnotetext{
${ }^{1}$ Abbreviations used in this paper: CoA, coenzyme A; DCA, dichloroacetate; PBS, phosphate-buffered saline, Dulbecco's " $A$ " solution; PDC, pyruvate dehydrogenase complex; PDH, pyruvate dehydrogenase; $\mathrm{PDH}_{\mathrm{a}}$, active, or dephosphorylated form of $\mathrm{PDH} ; \mathrm{PDH}_{\mathrm{b}}$, inactive or phosphorylated form of PDH; TPP, thiamin pyrophosphate.
} 
PDC activity is acutely regulated at two levels. Acetyl-CoA and NADH, the reaction products, exert product inhibition by competing with the substrates, $\mathrm{CoA}$ and $\mathrm{NAD}^{+}$, respectively (4-6). Additionally, PDC activity is determined by the degree of phosphorylation of PDH. The phosphorylation in turn depends on the relative activities of $\mathrm{PDH}_{\mathrm{a}}$ kinase and $\mathrm{PDH}_{\mathrm{b}}$ phosphatase which are subject to control by various metabolites $(1,2,7,8) . \mathrm{PDH}_{\mathrm{a}}$ kinase is activated by acetyl-CoA and NADH $(9,10)$ and inhibited by pyruvate, CoA, $\mathrm{NAD}^{+}, \mathrm{TPP}$, and ADP $(9,11-17)$. The kinase is also inhibited by dichloroacetate (DCA), a hypoglycemic agent $(17,18)$, which probably acts as an analog of pyruvate. The $\mathrm{PDH}_{\mathrm{b}}$ phosphatase is activated by $\mathbf{M g}^{++}$ and $\mathrm{Ca}^{++}(12,19,20)$ and inhibited by $\mathrm{F}^{-}(12)$. The phosphorylation-dephosphorylation process furnishes a major regulatory mechanism whereby the rate of pyruvate oxidation can be controlled by availability of pyruvate and metal ions and changes in the $\mathrm{NAD}^{+} /$ $\mathrm{NADH}, \mathrm{CoA} /$ acetyl-CoA, and ADP/ATP ratios.

Numerous cases have been reported in which a defect in the pyruvate oxidation system has been proposed or tested (21-23). The clinical disorders involved in these cases include lactic acidemia, motor and mental retardation, and other neurological defects. Blass et al. (21) have correlated the severity of clinical symptoms and the age of onset with the residual PDC activity found in cultured fibroblasts. Various attempts have also been made to measure the activities of the component enzymes of PDC, and the deficiencies in overall pyruvate oxidation have been attributed to defects in specific enzymes, including abnormalities in kinetic parameters $(21,23-38)$.

The PDC activity measurements in the previous studies, particularly those conducted with disrupted cell preparations, have the disadvantage that they do not take into account the phosphorylation state of PDC. Since the activation state of this enzyme can vary widely, depending on the metabolic situation, it is important that this parameter be controlled. The fully activated enzyme probably furnishes the most reliable estimates of enzymatic activity for studies of PDC deficiencies.

In the present paper, we present evidence to show that PDC, in preparations from untreated, cultured human skin fibroblasts, appears to be $90-95 \%$ inactivated. Measurements of PDC activity are thus subject to considerable error and can conceivably give misleading results. The full activity of PDC can be expressed by pretreatment of the fibroblasts with the activator DCA or by treating the disrupted fibroblasts with $\mathrm{PDH}_{\mathrm{b}}$ phosphatase or metal ions or both. These procedures have been used to measure PDC activity in fibroblasts with a series of normal controls, patients with unexplained lactic acidosis and two cases of PDC deficiency.
A preliminary account of some of these studies has been presented previously.

\section{METHODS}

Chemicals, enzymes. $\quad\left[1-{ }^{14} \mathrm{C}\right] \mathrm{Pyruvic}$ acid and $\left[2-{ }^{14} \mathrm{C}\right] \mathrm{pyru}-$ vic acid were obtained from New England Nuclear, Boston, Mass. $\left[2-{ }^{14} \mathrm{C}\right]$ Pyruvic acid was further purified before use on cellulose thin-layer chromatogram (Eastman Kodak Co., Rochester, N. Y.) using $n$-butanol:formic acid: $\mathrm{H}_{2} \mathrm{O}(95: 5: 10)$ as the mobile phase. $\left[1-{ }^{14} \mathrm{C}\right]$ Pyruvic acid was routinely dissolved in $30 \mathrm{mM} \mathrm{HCl}$ with added carrier pyruvic acid (Sigma Chemical Co., St. Louis, Mo.) to give a $50 \mathrm{mM}$ solution which contained $0.5 \mu \mathrm{Ci} / \mu \mathrm{mol}$. This solution was stored in small aliquots at $-20^{\circ} \mathrm{C}$. Prior to use, contaminating $\left[1{ }^{14} \mathrm{CO}_{2}\right]$ was removed from the solution by incubating in an assay vial (40) for at least $1 \mathrm{~h}$ with hyamine hydroxide (New England Nuclear).

Purified PDC from bovine heart (41) was a gift from Dr. L. J. Reed, University of Texas, Austin, Tex. $\mathrm{PDH}_{\mathrm{b}}$ phosphatase was purified from bovine heart according to Siess and Wieland (42) through step 5. The phosphatase was further purified by centrifuging twice in a Beckman L2-65 ultracentrifuge (Beckman Instruments, Fullerton, Calif.) with a type 42.1 rotor at $70,000 \mathrm{~g}$ for $90 \mathrm{~min}$. This preparation reactivated bovine heart $\mathrm{PDH}_{\mathrm{b}}$ which had been rendered $95 \%$ inactive by treatment with $0.02 \mathrm{mM}$ ATP (41). The phosphatase had a specific activity of $12.8 \mathrm{mU}$ when expressed as PDC activated per minute per milligram of phosphatase protein at $30^{\circ} \mathrm{C}$. The purified phosphatase contained a slight amount of contaminating PDC activity $(0.26 \mathrm{nmol} / \mathrm{min}$ per $\mathrm{mg})$. All the PDC assays using this phosphatase preparation as activation agent have been corrected for the contaminating PDC activity.

All other chemicals and enzymes were obtained from commercial suppliers at the highest grade available and used without further purification.

Radioactive measurements. Radioactivity was measured on a Packard Model 3320 Tri-Carb Scintillation Spectrometer (Packard Instrument Co., Downers Grove, Ill.) using scintillant Econofluor (New England Nuclear) for ${ }^{14} \mathrm{CO}_{2}$ measurements and Formula 963 (New England Nuclear) for determination of radioactivity in aqueous samples.

Fibroblast cultures. Human skin fibroblasts were grown in Eagle's minimum essential medium with $4 \times$ concentration of vitamins and amino acids (Gibco Laboratories, Grand Island Biological Co., Grand Island, N. Y.), supplemented with $15 \%$ fetal bovine serum, $100 \mathrm{U} / \mathrm{ml}$ penicillin, and $100 \mu \mathrm{g} / \mathrm{ml}$ streptomycin. The cells were fed twice a week, and harvested 5-7d past confluency. To harvest the cells, the tissue culture flasks were rinsed twice with $0.5 \mathrm{mM}$ EGTA in $\mathrm{Ca}^{++}, \mathrm{Mg}^{++}$-free phosphate-buffered saline (Dulbecco's "A" solution) (PBS), followed by treatment with $0.5 \%$ trypsin (trypsin 1:250) (Difco Laboratories, Detroit, Mich.), in National Institutes of Health medium 307 at $37^{\circ} \mathrm{C}$ for 5-10 min. One-half volume of the growth medium was then added, and the cells were collected by low-speed centrifugation. The cells were further washed twice with PBS. Only cells of early passage (5-15) were used in the experiments. The cell cultures were spot checked for Mycoplasma contamination either by Microbiological Associates (Bethesda, Md.) or in a few cases as a courtesy of Dr. J. A. Barranger of National Institutes of Health, Bethesda, Md. The cells used in these experiments were free from Mycoplasma contamination on the basis of the negative results of such examinations. As we will report elsewhere, ${ }^{2}$ we have found that

${ }^{2}$ Miller Paulson, S., K-F. R. Sheu, and M. F. Utter. Unpublished data. 
fibroblasts contaminated with Mycoplasma behave very differently from normal fibroblasts during the activation and inactivation of PDC. This property appears to provide a useful additional method for detection of the presence of Mycoplasma. Fibroblast lines were obtained as follows: IMR90 and GM3093 from the Human Genetic Mutant Cell Repository, Camden, N. J.; TC78761 and TC78766 from Dr. A. M. Glosgow, Children's Hospital, National Medical Center, Washington, D. C.; SK8177, SK5616, and SK8167 from Dr. J. C. Haworth, Health Science Center, Children's Hospital, Winnipeg, Manitoba; B.J.R., D.R., L.R., and B.R. from Dr. J. P. Blass, Cornell University Medical Center, New York, N. Y.; M.L. from Dr. D. Vine, Mt. Sinai Hospital, New York, N. Y.; B.J. from Dr. K. N. Rosenbaum, Children's Hospital, National Medical Center, Washington, D. C.; G-1 and G-2 from Dr. I. A. Schaefer, Cleveland Metropolitan General Hospital, Cleveland, Ohio; TC346 and TC349 from Dr. D. Kerr, University Hospitals, Cleveland, Ohio; TC194, TC313, and TC318 from Cytogenetics Laboratory, Case Western Reserve University, Cleveland, Ohio, and W.P. from Dr. D. C. Chuang, Veterans Administration Hospital, Cleveland, Ohio.

Cell treatment and PDC assay. Immediately after harvesting, the cells were suspended at $\sim 5 \mathrm{mg}$ protein $/ \mathrm{ml}$ in PBS, which contained either $5 \mathrm{mM}$ DCA or $15 \mathrm{mM} \mathrm{NaF}$. These suspensions were incubated at $37^{\circ} \mathrm{C}$ for $15 \mathrm{~min}$ in a water-bath shaker with constant gentle gyratory shaking. The pretreatment process was stopped by adding $1 / 3 \mathrm{vol}$ of ice-cold "stopping mixture" (43) which contained $40 \% \mathrm{vol} / \mathrm{vol}$ ethanol, 25 $\mathrm{mM} \mathrm{NaF}, 25 \mathrm{mM}$ EDTA, and $4 \mathrm{mM}$ dithiothreitol at pH 7.4. The suspension was then frozen rapidly in a dry ice-ethanol mixture and stored at $-76^{\circ} \mathrm{C}$. The enzymatic assays were normally performed within $48 \mathrm{~h}$ after freezing.

For assay, the fibroblast suspension was further frozen and thawed twice. PDC activity was determined by measurement of ${ }^{14} \mathrm{CO}_{2}$ production from $\left[1-{ }^{14} \mathrm{C}\right]$ pyruvate, by modifying the method of Leiter et al. (40). The assay mix with a final volume of $0.2 \mathrm{ml}$ and $\mathrm{pH}$ of 8.0 contained $\mathrm{K}$ phosphate, $50 \mathrm{mM}$; $\mathrm{K}$ oxalate, $15 \mathrm{mM}$; MgCl, $2 \mathrm{mM}$; CoA, $0.3 \mathrm{mM}$; dithiothreitol, $1 \mathrm{mM}$; $\mathrm{NAD}^{+}, 2 \mathrm{mM}$; TPP, $0.1 \mathrm{mM}$; $\left[1{ }^{14} \mathrm{C}\right]$ pyruvate, $0.5 \mathrm{mM}$; phosphotransacetylase, $1 \mathrm{U} / \mathrm{ml}$ (Boehringer Mannheim Biochemicals, Indianapolis, Ind.); and the fibroblast suspension, 20 or $30 \mu \mathrm{l}$, containing $0.05-0.15 \mathrm{mg}$ protein. The assay mix (except the fibroblast extract and $\left[1-{ }^{14} \mathrm{C}\right]$ pyruvate) was pipetted into assay vials made by shortening test tubes $(10 \mathrm{~mm})$ and cutting out vents. These tubes were suspended from rubber serum stoppers which were then used to cover snap-cap scintillation vials containing $0.2 \mathrm{ml}$ hyamine hydroxide. These vials were put in a $37^{\circ} \mathrm{C}$ water bath shaker; and the reaction was started by injecting the fibroblast extract and $\left[1-{ }^{14} \mathrm{C}\right]$ pyruvate into the reaction mix through the septum of the rubber stopper with Hamilton syringes fitted with PB-600 repeating dispensers. After $4 \mathrm{~min}$ incubation, the reaction was stopped by injecting $50 \mu \mathrm{l}$ of $10 \%$ TCA, and the incubation was continued for another $1 \mathrm{~h}$. The serum stoppers and reaction vials were then removed, and the radioactivity associated with hyamine hydroxide was measured. CoA was omitted to serve as a blank except where otherwise indicated. Three to five replicates were performed to obtain each data point. For a complete assay which includes determination of PDC activity in untreated cells and after treatment with DCA or $\mathrm{NaF}$, cells from $300 \mathrm{~cm}^{2}$ were required.

Protein was determined according to Lowry et al. (44), using bovine serum albumin as standard.

Activation of PDC in cell-free homogenates. The cell suspension prepared as described above was centrifuged at top speed in an Eppendorf model 3200 centrifuge for $30 \mathrm{~s}$ and the resulting cell pellets were quickly frozen in a dry ice-ethanol bath. The pellets were thawed in a solution containing $\mathrm{K}$ phosphate, $10 \mathrm{mM}$, pH 7.4; EDTA, $1 \mathrm{mM} ; \mathrm{MgCl}_{2}$, $2 \mathrm{mM}$; fatty acid-poor bovine serum albumin, $0.5 \mathrm{mg} / \mathrm{ml}$ (Sigma Chemical Co.); and fibroblasts, $3 \mathrm{mg}$ protein $/ \mathrm{ml}$, homogenized in a ground glass homogenizer for 6-8 passes, followed by two cycles of freezing and thawing. To the homogenate were added (as final concentrations) $\mathrm{MgCl}_{2}, 15 \mathrm{mM}$; $\mathrm{CaCl}_{2}, 0.5 \mathrm{mM}$; TPP, $40 \mu \mathrm{M}$; DCA, $2 \mathrm{mM}$; and $\mathrm{PDH}_{\mathrm{b}}$ phosphatase, $2 \mathrm{mg} / \mathrm{ml}$. Either $\mathrm{PDH}_{\mathrm{b}}$ phosphatase or $\mathrm{PDH}_{\mathrm{b}}$ phosphatase plus the other components listed above were omitted from control incubations. Aliquots of $20 \mu \mathrm{l}$ were withdrawn at different time intervals for measurement of PDC activity by the procedures described above, except that $1 \mathrm{mM}$ EDTA was also present in the assay medium.

Identification of acetyl-CoA as a reaction product. The PDC reaction product, acetyl-CoA, was converted to citrate by adding citrate synthase and oxalacetate and the citrate isolated chromatographically. For these experiments, the reaction mixture of $1 \mathrm{ml}$ contained the components described above at the same concentrations except that $\left[1-{ }^{14} \mathrm{C}\right]$ pyruvate was replaced by $\left[2-{ }^{14} \mathrm{C}\right]$ pyruvate, and phosphotransacetylase was replaced by $1 \mu \mathrm{mol}$ of freshly dissolved oxalacetate and $7 \mu \mathrm{g}$ of citrate synthase (Boehringer Mannheim Biochemicals). After $4 \mathrm{~min}$ incubation, the reaction was stopped by adding $50 \mu \mathrm{mol}$ of carrier citrate and heating in a boiling water bath for $2 \mathrm{~min}$. The heated suspension was chromatographed on a DEAE-Sephadex A-25 ion exchange column (Pharmacia Fine Chemicals, Piscataway, N. J.). Citrate was quantitated spectrophotometrically by measuring the oxidation of NADH in the presence of citrate lyase (BoehringerMannheim Biochemicals) and malate dehydrogenase (Sigma Chemical Co.). The amount of acetyl-CoA formed was calculated by dividing the total radioactivity associated with citrate by the known specific activity of the $\left[2-{ }^{14} \mathrm{C}\right]$ pyruvate.

\section{RESULTS}

Activation of PDC in fibroblasts. When intact fibroblasts obtained from infants were incubated with $5 \mathrm{mM}$ DCA and then disrupted and assayed for PDC activity, the specific activity reached a value of 5.5-6 $\mathrm{nmol}{ }^{14} \mathrm{CO}_{2}$ produced/min per $\mathrm{mg}$ of fibroblasts protein after 5 min activation and remained at that level at least through a $17 \mathrm{~min}$ activation period (Fig. 1). Lower concentrations of DCA such as $0.5 \mathrm{mM}$ were insufficient to activate the PDC completely, even in $17 \mathrm{~min}$. Preincubation with $\mathrm{NaF}$ caused a drop of $\sim 50 \%$ in the control level over a 10 -min period. The control values were relatively steady over the same incubation period. Although the DCA-incubated values were relatively consistent (5-6 $\mathrm{nmol} / \mathrm{min}$ per $\mathrm{mg}$ protein), the values for untreated normal cells varied considerably (from 0.3 to $1.4 \mathrm{nmol} / \mathrm{min}$ per $\mathrm{mg}$ ). That shown in Fig. 1 was the highest of any line yet tested. Likewise, the values for $\mathrm{NaF}$-treated cells varied considerably although they were always low. As shown in Fig. 2, the activity of PDC was linear for only $\sim 4$ min during incubation of the DCA-treated cells, and it was necessary to restrict the assay to this period. As is also shown in Fig. 2, the activity of the PDC from untreated cells appeared to be linear with time for a longer period. The production of 


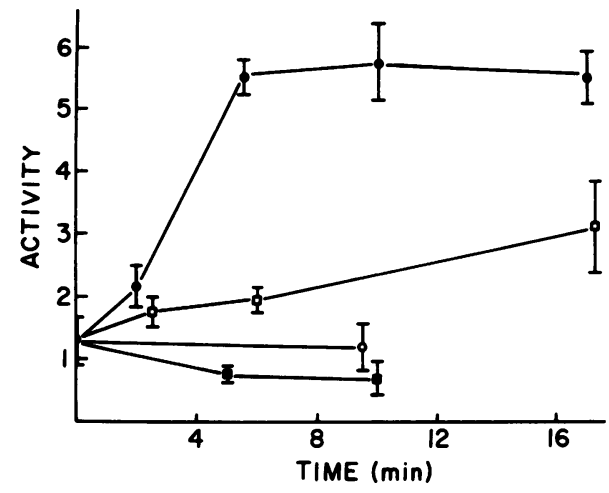

FIGURE 1 Time-course of activation and inactivation of PDC in fibroblasts by dichloroacetate and $\mathrm{NaF}$. The values are mean \pm SD $(n=3-4)$. $\bigcirc$, control $\odot, 5 \mathrm{mM}$ DCA; $\square, 0.5 \mathrm{mM}$ DCA;, $15 \mathrm{mM}$ NaF. Assay conditions were described in Methods. Activity is expressed as nanomoles ${ }^{14} \mathrm{CO}_{2}$ produced per minute per milligram protein.

${ }^{14} \mathrm{CO}_{2}$ from $\left[1-{ }^{14} \mathrm{C}\right]$ pyruvate was linear with protein concentration up to $1 \mathrm{mg} / \mathrm{ml}$ of the assay mix, and assays were conducted with $0.15-0.75 \mathrm{mg}$ protein $/ \mathrm{ml}$.

The effects of the various cofactors and substrates on the rate of pyruvate oxidation by PDC are shown in Table I. The results are presented as counts present at 0 and $4 \mathrm{~min}$. The former values show the actual extent of blank value. The reaction is almost completely dependent on the presence of TPP, CoA, NAD ${ }^{+}$, and $\mathrm{Mg}^{++}$. Routinely, CoA was omitted to serve as a blank. In an early stage of this study, the blanks were unacceptably high, but this problem has been largely obviated by proper storage of the pyruvate, by preincubation of the pyruvate with hyamine hydroxide and by

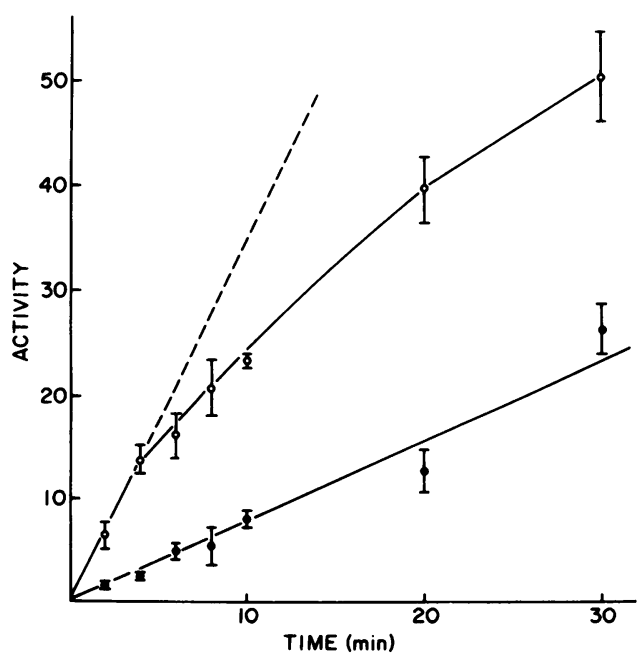

FIGURE 2 The activity of PDC in fibroblasts as a function of the incubation time. The values are mean $\pm S D(n=3-4)$. $\bigcirc$, DCA pre-treated cells; 0 , untreated cells. Activity is expressed as nanomoles ${ }^{14} \mathrm{CO}_{2}$ produced per milligram protein.
TABLE I

Cofactor Requirement of DCA-activated PDC Assay

\begin{tabular}{|c|c|c|c|}
\hline \multirow[b]{2}{*}{ Assay condition } & \multicolumn{3}{|c|}{${ }^{14} \mathrm{CO}_{2}$} \\
\hline & $0 \min$ & $4 \min$ & Net* \\
\hline & \multicolumn{3}{|c|}{ cpm } \\
\hline Complete & $131 \pm 11$ & $2177 \pm 125$ & 2,046 \\
\hline$-T P P$ & $116 \pm 4$ & $228 \pm 19$ & 112 \\
\hline$-\mathrm{CoA}$ & $122 \pm 11$ & $240 \pm 24$ & 118 \\
\hline$-\mathrm{NAD}^{+}$ & $300 \pm 18$ & $351 \pm 47$ & 51 \\
\hline$-\mathrm{Mg}^{++}$ & $175 \pm 19$ & $223 \pm 16$ & 48 \\
\hline$-\mathrm{CoA},-\mathrm{NAD}^{+},-\mathrm{Mg}^{++}$ & $163 \pm 23$ & $204 \pm 9$ & 81 \\
\hline
\end{tabular}

The assays were performed with $90.5 \mu \mathrm{g}$ protein in each tube. The specific radioactivity of $\left[1-{ }^{14} \mathrm{C}\right]$ pyruvate was $1,220 \mathrm{cpm} /$ nmol. Values are mean $\pm \operatorname{SD}(n=3-4)$.

* Net is the difference of counts at 0 min subtracted from that at $4 \mathrm{~min}$.

addition of the dithiothreitol and CoA to the assay medium just prior to addition of enzyme. Even so, the blank formation of ${ }^{14} \mathrm{CO}_{2}$ could not be completely eliminated, as shown in Table I.

Relative rates of production of $\mathrm{CO}_{2}$ and acetyl-CoA as products. To show that measurement of ${ }^{14} \mathrm{CO}_{2}$ produced from $\left[1-{ }^{14} \mathrm{C}\right]$ pyruvate constitutes a valid assay for the complete reaction catalyzed by PDC, the rate of production of another major product, acetyl-CoA, was compared with that of ${ }^{14} \mathrm{CO}_{2}$ production. The assay reaction was initiated with $\left[2-{ }^{14} \mathrm{C}\right]$ pyruvate and the radioactive product $\left[1-{ }^{14} \mathrm{C}\right]$ acetyl-CoA was trapped as $\left[{ }^{14} \mathrm{C}\right]$ citrate in the presence of oxalacetate and citrate synthase. Citrate was isolated by chromatography on a DEAE-Sephadex A-25 column as depicted in Fig. 3. A radioactive peak, well separated from the initial peak of $\left[2-{ }^{14} \mathrm{C}\right]$ pyruvate, co-migrated with authentic citrate added as carrier. The latter was recovered in $96 \%$ yield. As shown in Fig. 3, the second radioactive peak was absent in the parallel experiment from which $\mathrm{CoA}$ was omitted. The specific radioactivity of the citrate was constant over most of the peak, indicating that the radioactive product was citrate. The enzymatic activity, calculated from the amount of citrate formation, was 3.86 $\mathrm{nmol} / \mathrm{min}$ per $\mathrm{mg}$ protein. In a similar experiment where the $\left[2-{ }^{14} \mathrm{C}\right]$ pyruvate was replaced by $\left[1-{ }^{14} \mathrm{C}\right]-$ pyruvate, and enzymatic activity calculated from ${ }^{14} \mathrm{CO}_{2}$, production was $3.67 \pm 0.18 \mathrm{nmol} / \mathrm{min}$ per $\mathrm{mg}$ protein. Thus, the stoichiometry of product formation, acetyl-CoA/ $\mathrm{CO}_{2}=1.02$, was in excellent agreement with the expected value of 1.0 .

Activation of PDC in cell-free homogenates. To establish that the mechanism of DCA activation involves an alteration of the dephosphorylation/phosphorylation ratio in favor of the former process and further to establish that DCA activates the enzymatic complex completely, dephosphorylation by other pro- 


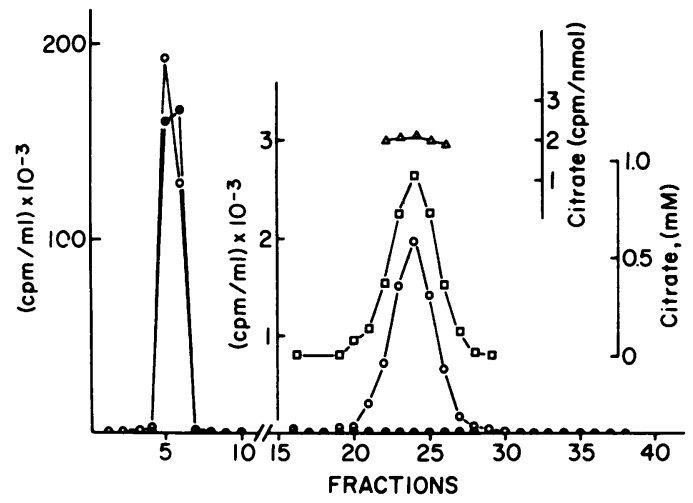

Figure 3 Formation of $\left[{ }^{14} \mathrm{C}\right]$ citrate of PDC reaction from $\left[2-{ }^{14} \mathrm{C}\right]$ pyruvate when coupled with citrate synthase reaction. The heat-inactivated reaction mixture (Methods) was chromatographed on a DEAE-Sephadex A-25 column $(1.0 \times 5.5$ $\mathrm{cm})$. After washing the column with $40 \mathrm{ml} 0.4 \mathrm{M} \mathrm{NH}_{4} \mathrm{OAc}, \mathrm{pH}$ $5.9,36 \mathrm{ml}$ of $0.4-1.5 \mathrm{M}$ linear gradient of the same buffer was applied starting from fraction 15 . Fractions of $1.5 \mathrm{ml}$ were collected. $\bigcirc$, radioactivity, complete reaction mixture; radioactivity, CoA omitted; $\square$, citrate concentration, $\Delta$, specific radioactivity of citrate.

cedures was attempted. While $\mathrm{PDH}_{\mathrm{a}}$ kinase is believed to be bound tightly to the PDC complex, $\mathrm{PDH}_{\mathrm{b}}$ phosphatase is probably associated only loosely with the complex after disruption of the cells and their mitochondria (20, 41). Further, high concentrations of $\mathrm{Mg}^{++}$ and $\mathrm{Ca}^{++}$are required for binding of the phosphatase to the complex (20). Therefore, the endogenous phosphatase may not be sufficient to provide rapid or perhaps maximal activation in broken cell preparations. Fig. 4 shows that the addition of $\mathrm{Mg}^{++}$and $\mathrm{Ca}^{++}$to stimulate the phosphatase, along with DCA and TPP to inhibit the kinase, provided reasonably good activa-

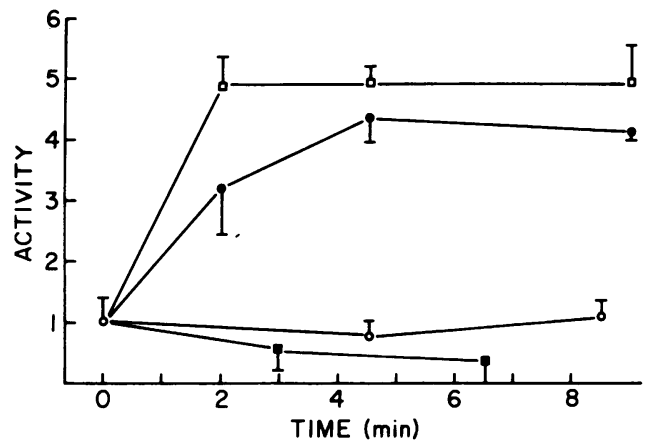

FIgURE 4 Phosphatase activation and ATP inactivation of PDC in fibroblast homogenate. Aliquots of $20 \mu \mathrm{l}$ were withdrawn at times indicated from the cell-free homogenate (Methods) for enzyme assay. Values are mean $\pm \operatorname{SD}(n=3-4)$. $\bigcirc$, control; $, 15 \mathrm{mM} \mathrm{MgCl} 2,2 \mathrm{mM} \mathrm{DCA}, 0.5 \mathrm{mM} \mathrm{CaCl}_{2}$ and $0.4 \mathrm{mM}$ TPP added; $\square, 2 \mathrm{mg} / \mathrm{ml}$ phosphatase also added in the latter incubation;, $3 \mathrm{mM}$ ATP added into the control incubation. Activity is expressed as nanomoles per minute per milligram protein. tion in a disrupted cell experiment. However, the addition of external $\mathrm{PDH}_{\mathrm{b}}$ phosphatase gave a more rapid rate of activation, although the maximal value reached was probably not significantly higher. Addition of ATP resulted in a lowering of the initial control value, demonstrating the presence of an active kinase during these conditions. In an accompanying experiment, in which the cells were preincubated with $5 \mathrm{mM}$ DCA for $15 \mathrm{~min}$ and homogenized with $2 \mathrm{mM}$ DCA and $40 \mu \mathrm{M}$ TPP, the PDC activities were $4.5 \pm 0.46$ and $4.0 \pm 0.91 \mathrm{nmol} / \mathrm{min}$ per $\mathrm{mg}$ protein after 4 and 7.5 min, respectively. In a later part of the investigation, DCA and TPP were omitted from the medium. No significant difference was found (data not shown). These results indicate that PDC can be activated to about the same extent by any of the three types of treatment, although the addition of $\mathrm{PDH}_{\mathrm{b}}$ phosphatase may be the most effective procedure.

Application of activation procedures to normal cell lines. Table II lists the PDC activities of cell cultures that we have assayed and consider to be within the normal range. Infant skin fibroblasts (except for IMR90, which is a lung culture) consistently exhibited maximal PDC activities up to $4-6 \mathrm{nmol} / \mathrm{min}$ per $\mathrm{mg}$ protein after activation with DCA, while cells obtained from older individuals showed somewhat lower activities. The decrease appears to take place in early childhood. Table II also shows that untreated values are always much lower than those obtained after activation and that these values exhibit a wider range. $\mathrm{NaF}$-treated cells have still lower activities and also vary considerably between different cell lines. These results demonstrate the values from untreated cells and especially from those treated with $\mathrm{NaF}$ provide much less reliable estimates of the activity of PDC.

Assays on PDC-deficient cell lines. These methods have also been applied to cells from two PDC-deficient patients, who have been previously studied by Blass et al. (patient B.J.R. [26, 45]; patient E.G. [46]). The results shown in Table III indicate that both of these patients are indeed PDC deficient even when DCA activation is used; indeed, the defects now appear to be more severe than previously realized because of the higher normal values. After DCA activation, fibroblasts from B.J.R. had an activity of only $0.1 \mathrm{nmol} / \mathrm{min}$ per $\mathrm{mg}$, while those from E.G. were only $0.28 \mathrm{nmol} / \mathrm{min}$ per mg protein. Fibroblasts from the parents and a sibling of B.J.R. were also tested. The results (Table III) suggest that the sibling has activity in the normal range for his age group, but that the parents have activities half or less than those of any other individuals tested thus far (cf. Table II), except the two patients.

\section{DISCUSSION}

The studies presented here demonstrate that PDC in fibroblasts, as in all other mammalian systems tested 
TABLE II

PDC Activities in Fibroblasts That Contain Normal Amount of Total Enzyme

\begin{tabular}{|c|c|c|c|c|c|c|}
\hline \multirow[b]{2}{*}{ Cell line } & \multirow[b]{2}{*}{ Sex } & \multirow[b]{2}{*}{ Age } & \multirow[b]{2}{*}{ Remarks } & \multicolumn{3}{|c|}{ PDC* } \\
\hline & & & & DCA-activated & Untreated & $\mathrm{NaF}$-inactivated \\
\hline & & & & \multicolumn{3}{|c|}{ nmol ${ }^{14} \mathrm{CO}_{2} /$ mintmg protein } \\
\hline PW & $\mathbf{M}$ & Newborn & Normal control & $5.8 \pm 0.66$ & $1.23 \pm 0.067(2)$ & $0.45 \pm 0.066(5)$ \\
\hline TC318 & $\mathbf{F}$ & Newborn & Possible renal agnesis & $4.9 \pm 0.21$ & $0.65 \pm 0.094(4)$ & $0.52 \pm 0.142(4)$ \\
\hline TC313 & $\mathbf{F}$ & $3 \mathrm{~d}$ & Potter's Syndrome & $5.1 \pm 0.20$ & $0.34 \pm 0.002(3)$ & $0.30 \pm 0.35$ \\
\hline IMR90 & $\mathbf{F}$ & $16 \mathrm{wk}$ & $\begin{array}{l}\text { Normal control, fibroblast lung } \\
\text { culture }\end{array}$ & $3.2 \pm 0.092(3)$ & $0.57 \pm 0.117(3)$ & - \\
\hline TC349 & $\mathbf{M}$ & $4 \mathrm{mo}$ & Lactic acidosis & $5.5 \pm 0.38$ & $1.36 \pm 0.153(3)$ & $0.62 \pm 0.254(4)$ \\
\hline TC78766 & $\mathbf{M}$ & $10 \mathrm{mo}$ & Lactic acidosis, fructose intolerance & $5.8 \pm 0.12$ & $0.33 \pm 0.050(3)$ & $0.005 \pm 0.070(4)$ \\
\hline TC78761 & & infant & Normal control & $4.7 \pm 0.21$ & $0.41 \pm 0.134(4)$ & $0.059 \pm 0.23$ \\
\hline SK8167 (GB) & $\mathbf{M}$ & $4 \mathrm{mo}$ & $\begin{array}{l}\text { Lactic acidosis, pyruvate carboxy- } \\
\text { lase deficiency }\end{array}$ & $3.5 \pm 0.24$ & $0.71 \pm 0.122(8)$ & $0.054 \pm 0.156(3)$ \\
\hline SK5616 (DM) & $\mathbf{M}$ & $23 \mathrm{mo}$ & $\begin{array}{l}\text { Lactic acidosis, pyruvate carboxy- } \\
\text { lase deficiency }\end{array}$ & $3.6 \pm 0.68$ & $0.62 \pm 0.069(3)$ & $0 \pm 0.075(4)$ \\
\hline SK8177 (RS) & $\mathbf{M}$ & & $\begin{array}{l}\text { Lactic acidosis, pyruvate carboxy- } \\
\text { lase deficiency }\end{array}$ & $4.9 \pm 0.20$ & $1.20 \pm 0.293(4)$ & $0.17 \pm 0.080(4)$ \\
\hline ML & $\mathbf{F}$ & $20 \mathrm{mo}$ & $\begin{array}{l}\text { Lactic acidosis, mitochondrial } \\
\text { myopathy }\end{array}$ & $2.7 \pm 0.49$ & $0.53 \pm 0.064(4)$ & $0.104 \pm 0.082(4)$ \\
\hline BJ & $\mathbf{M}$ & $3 \mathrm{yr}$ & Lactic acidosis & $4.6 \pm 0.62$ & $0.50 \pm 0.194(4)$ & $0.042 \pm 0.040(4)$ \\
\hline TC346 & $\mathbf{M}$ & $5 \mathrm{yr}$ & $\begin{array}{l}\text { Lactic acidosis, fasting hypo- } \\
\text { glycemia, galactose intolerance }\end{array}$ & $2.7 \pm 0.25$ & $0.44 \pm 0.066(4)$ & $0.091 \pm 0.080(4)$ \\
\hline TC194 & $\mathbf{F}$ & Adult & Turner Syndrome & $2.3 \pm 0.68$ & $0.60 \pm 0.278(3)$ & - \\
\hline G-1 & & Adult & Normal control & $2.5 \pm 0.26$ & $0.30 \pm 0.088(4)$ & $0.18 \pm 0.108(4)$ \\
\hline G-2 & & Adult & Normal control & $2.0 \pm 0.11$ & $0.106 \pm 0.189(3)$ & $0.154 \pm 0.130$ \\
\hline
\end{tabular}

* Values are mean $\pm \mathrm{SD}$. Numbers of determinations are in parentheses.

thus far, is subject to regulation by phosphorylation and dephosphorylation. Thus, these cells may be subject to wide variations in the catalytic activity of this enzyme, depending on the metabolic situation, hormonal influences, and other factors. Assay of PDC activity without proper regard for the phosphorylation state may give a very misleading picture of the total activity of this enzymatic complex. Mammalian tissues have been shown to vary widely in their proportion of active and inactive forms, e.g., active PDC: $20-30 \%$ in rat liver $(51,52)$; about $60 \%$ in rat heart and adipose tissue $(51,53-57)$.
Examination of the literature shows that previous measurements of PDC activity in disrupted fibroblasts range from 0.14 to $0.6 \mathrm{nmol} / \mathrm{min}$ per $\mathrm{mg}$ protein $(24$, $29-31,33,35,38,46,48-50)$. It is surprising to note that the highest of these values could be no higher than $20 \%$ of the levels of activity observed here after activation, and some of the previous values may be as low as $3 \%$ of the expected maximal activity. These observations suggest that the PDC in isolated fibroblasts exists largely in the inactivated phosphorylated state. However, such low values may be an artifact of isolation and handling of the cells, and it seems

TABLE III

PDC in Fibroblasts of Enzyme-deficient Patients, BJR and EG, and BJR's Family

\begin{tabular}{|c|c|c|c|c|c|}
\hline \multirow[b]{2}{*}{ Cell line } & \multirow[b]{2}{*}{ Sex } & \multirow[b]{2}{*}{ Age } & \multirow[b]{2}{*}{ Remarks } & \multicolumn{2}{|c|}{ PDC activities* } \\
\hline & & & & DCA-activated & Untreated \\
\hline & \multicolumn{3}{|c|}{$y r$} & \multicolumn{2}{|c|}{$\mathrm{nmol}^{14} \mathrm{CO}_{2} / \mathrm{min} / \mathrm{mg}$ protein } \\
\hline BJR & $\mathbf{M}$ & 8 & Patient & $0.10 \pm 0.054(3)$ & $0.083 \pm 0.065$ \\
\hline DR & $\mathbf{M}$ & 5 & Sibling & $2.3 \pm 0.18$ & $0.34 \pm 0.022$ \\
\hline LR & $\mathbf{F}$ & 31 & Mother & $0.74 \pm 0.042(2)$ & $0.051 \pm 0.0044$ \\
\hline BR & $\mathbf{M}$ & 43 & Father & $1.05 \pm 0.080(3)$ & $0.32 \pm 0.058$ \\
\hline EG (GM3093) & $\mathbf{F}$ & $4-1 / 2$ & Patient & $0.28 \pm 0.513$ & $0.03 \pm 0.124$ \\
\hline
\end{tabular}

* Values are mean $\pm \mathrm{SD}$. Numbers in parentheses are numbers of determinations. 
likely that the rates of pyruvate oxidation in fibroblasts under physiological conditions are considerably higher.

It is important to note (Table III) that in the two cases of previously reported PDC deficiency included in the present study, the values of PDC activity were so low that they could be distinguished from the normal untreated fibroblast preparations. With the activation procedures, the deficiencies appear to be much more severe because of the much higher control values. The problem of detection of PDC deficiencies in untreated fibroblasts may become much more difficult in cases where the deficiency is less severe, e.g., in Friedreich's ataxia where PDC activities of $40-50 \%$ of normal have been reported $(34,49,58,59)$ by some investigators and normal activities by others (60). Results obtained with the familial study of patient B.J.R. (Table III), in which both parents exhibit approximately half the total PDC activity compared with normal control, and that of the sibling appears to be normal, indicate the inheritance nature of the PDC deficiency. Both parents are probably heterozygous carriers. It is interesting to note that Blass et al. (26), in their original studies on this parent, found that rates of pyruvate oxidation in both intact fibroblasts and white cells from the parents were about half the levels of those obtained with control cells. This relationship, however, could not be demonstrated in assays involving disrupted cells. The present method appears to be sensitive enough to detect certain genetic heterozygous states. Efforts are underway to apply this method to different cell types, e.g., leukocytes and amniotic cells, to provide biochemical basis for prenatal diagnosis.

The DCA activation procedure appears to provide a relatively simple and reproducible method for measuring maximal PDC activity in fibroblasts, but it has the disadvantage that relatively large numbers of cells are required. This is due mainly to the short period $(4 \mathrm{~min})$ when the activity is linear with time. The reason for the decrease in activity after $4 \mathrm{~min}$ is not clear. Lynen et al. (61) have suggested that the dihydrolipoyl transacetylase component of PDC may be subject to proteolysis, and it is possible that such an effect is being seen here. However, the preparation from untreated cells (Fig. 2) does not seem to be subject to the same decrease in activity, as would be expected if proteolysis were involved. As an alternative explanation, preliminary results from experiments in which $\mathrm{PDH}_{\mathrm{b}}$ phosphatase was added suggest that the length of the linear response with time can be greatly extended by the presence of the phsophatase. This result suggests that a shift toward increased phosphorylation is responsible for the decrease in activity with time. If these results are confirmed, the use of $\mathrm{PDH}_{b}$ phosphatase may be the preferred method of activation.

The present method of PDC measurement is aimed only at detecting defects in total activity of the complex, although the procedure could be modified to test for alterations in the $K_{\mathrm{m}}$ for the various substrates. The DCA method is probably not well adapted to detect changes in the regulatory components of the complex, the kinase and phosphatase, unless these are severe.

\section{ACKNOWLEDGMENTS}

The authors are grateful to the individuals (Methods) who provided the materials and assistance in this study. They also thank Dr. M. S. Patel and Dr. D. S. Kerr for their critical reading of the manuscript and valuable suggestions.

This work was supported by a grant from National Institutes of Health, AM 20478.

\section{REFERENCES}

1. Reed, L. J. 1974. Multienzyme complexes. Account of Chemical Research 7: 40-46.

2. Denton, R. M., P. J. Randle, B. J. Bridges, R. H. Cooper, A. L. Kerbey, H. T. Pask, D. L. Severson, D. Stainsbie, and S. Whitehouse. 1975. Regulation of mammalian pyruvate dehydrogenase. Mol. Cell. Biochem. 9: 27-53.

3. Linn, T. C., F. H. Pettit, and L. J. Reed. 1969. $\alpha$-Keto acid dehydrogenase complexes. X. Regulation of the activity of the pyruvate dehydrogenase complex from beef kidney mitochondria by phosphorylation and dephosphorylation. Proc. Natl. Acad. Sci. U. S. A. 62: 234-241.

4. Garland, P. B., and P. J. Randle. 1964. Control of pyruvate dehydrogenase in perfused heart by the intracellular concentration of acetyl-CoA. Biochem. J. 91: 6C-7C.

5. Bremer, J. 1969. Pyruvate dehydrogenase, substrate specificity and product inhibition. Eur. J. Biochem. 7: 535-540.

6. Tsai, C. S., M. W. Burgett, and L. J. Reed. 1973. $\alpha$-Keto acid dehydrogenase complexes. XX. A kinetic study of the pyruvate dehydrogenase complex from bovine kidney. $J$. Biol. Chem. 248: 8348-8352.

7. Randle, P. J. 1978. Pyruvate dehydrogenase complexmeticulous regulator of glucose disposal in animals. Trends Biochem. Sci. 3: 217-219.

8. Reed, L. J. 1976. Regulation of mammalian pyruvate dehydrogenase complex by phosphorylation and dephosphorylation. In Thiamine. C. J. Gubler, M. Fujiwara, and P. M. Dreyfus, editors. John Wiley \& Sons, New York. 19-27.

9. Pettit, F. H., J. W. Pelley, and L. J. Reed. 1975. Regulation of pyruvate dehydrogenase kinase and phosphatase by acetyl-CoA/CoA and NADH/NAD ratios. Biochem. Biophys. Res. Commun. 65: 575-582.

10. Roche, T. E., and R. J. Cate. 1976. Evidence for lipoic acid mediated NADH and acetyl-CoA stimulation of liver and kidney pyruvate dehydrogenase kinase. Biochem. Biophys. Res. Commun. 72: 1375-1383.

11. Linn, T. C., F. H. Pettit, F. Hucho, and L. J. Reed. 1969. $\alpha$ Keto acid dehydrogenase complexes. XI. Comparative studies of regulatory properties of the pyruvate dehydrogenase complexes from kidney, heart and liver mitochondria. Proc. Natl. Acad. Sci. U. S. A. 64: 227-234.

12. Hucho, F., D. D. Randall, T. E. Roche, M. W. Burgett, J. W. Pelley, and L. J. Reed. 1972. $\alpha$-Keto acid dehydrogenase complexes. XVII. Kinetic and regulatory properties of pyruvate dehydrogenase kinase and pyruvate dehydrogenase phosphatase from bovine kidney and heart. Arch. Biochem. Biophys. 151: 328-340.

13. Roche, T. E., and L. J. Reed. 1972. Function of the nonidentical subunits on mammalian pyruvate dehydrogenase. Biochem. Biophys. Res. Commun. 48: 840-846. 
14. Roche, T. E., and L. J. Reed. 1974. Monovalent cation requirement for ADP inhibition of pyruvate dehydrogenase kinase. Biochem. Biophys. Res. Commun. 59: 1341-1348.

15. Cooper, R. H., P. J. Randle, and R. M. Denton. 1974. Regulation of heart muscle pyruvate dehydrogenase kinase. Biochem. J. 143: 626-641.

16. Cate, R. L., and T. E. Roche. 1978. A unifying mechanism for stimulation of mammalian pyruvate dehydrogenase ${ }_{\mathrm{a}}$ kinase by reduced nicotinamide adenine dinucleotide, dihydrolipoamide, acetyl coenzyme A or pyruvate. J. Biol. Chem. 253: 496-503.

17. Pratt, M. L., and T. E. Roche. 1979. Mechanism of pyruvate inhibition of kidney pyruvate dehydrogenase kinase and synergistic inhibition by pyruvate and ADP.J. Biol. Chem. 254: 7191-7196.

18. Whitehouse, S., R. H. Cooper, and P. J. Randle. 1974. Mechanism of activation of pyruvate dehydrogenase by dichloroacetate and other hydrogenated carboxylic acids. Biochem. J. 141: 761-774.

19. Severson, D. L., R. M. Denton, H. T. Pask, and P. J. Randle. 1974. Calcium and magnesium ions as effectors of adipose tissue pyruvate dehydrogenase phosphate phosphatase. Biochem. J. 140: 225-237.

20. Pettit, F. H., T. E. Roche, and L. J. Reed. 1972. Function of calcium ions in pyruvate dehydrogenase phosphate activity. Biochem. Biophys. Res. Commun. 49: 563-571.

21. Blass, J. P., S. D. Cederbaum, R. A. P. Kark, and M. Rodriguez-Budelli. 1978. Pyruvate dehydrogenase deficiency in 35 patients. In Monographs in Human Genetics. O. Sperling and A. DeVries, editors. Karger, Basel 9: 12-15.

22. Blass, J. P. 1979. Disorders of pyruvate metabolism. Neurology 29: 280-286.

23. Blass, J. P. 1980. Pyruvate dehydrogenase deficiency. In Inherited disorders of carbohydrate metabolism. D. Burma, J. B. Holtman, and C. A. Pennuch, editors. University Park Press, Baltimore, Md. 239-268.

24. Blass, J. P., G. E. Gibson, and R. A. P. Kark. 1976. Pyruvate decarboxylase deficiency. In Thiamine. C. J. Gubler, M. Fujiwara, and P. M. Dreyfus, editors. John Wiley \& Sons, New York 321-332.

25. Farrel, D. F., A. F. Clark, C. R. Scott, and R. P. Wennberg. 1975. Absence of pyruvate decarboxylase activity in man: a cause of congenital lactic acidosis. Science (Wash. D. C.). 187: 1082-1084.

26. Blass, J. P., J. Avigan, and B. W. Ublendorf. 1970. A defect in pyruvate decarboxylase in a child with an intermittent movement disorder. J. Clin. Invest. 49: 423432.

27. Blass, J. P., D. Lonsdale, B. W. Ublendorf, and E. Ham. 1971. Intermittent ataxia with pyruvate decarboxylase deficiency. Lancet. I: 1302.

28. Farmer, T. W., L. Veath, A. L. Miller, J. S. O'Brien, and R. M. Rosenberg. 1973. Pyruvate decarboxylase deficiency in a patient with subacute necrotising encephalomyelopathy. Neurology. 23: 429.

29. Stomme, J. H., O. Borud, and P. J. Moe. 1976. Fetal lactic acidosis in a newborn attributable to a congenital defect of pyruvate dehydrogenase. Pediatr. Res. 10: 6266.

30. Falk, R. E., S. D. Cederbaum, J. P. Blass, G. E. Gibson, R. A. P. Kark, and R. E. Carrel. 1976. Ketonic diet in the management of pyruvate dehydrogenase deficiency. Pediatrics. 58: 713-721.

31. Wick, H., K. Schweizer, and R. Baumgartner. 1977. Thiamine dependency in a patient with congenital lacticacidemia due to pyruvate dehydrogenase deficiency. Agents Actions. 7: 405-410.

32. Robinson, B. H., J. Taylor, and W. G. Sherwood. 1977. Deficiency of dihydrolipoyl dehydrogenase (a component of the pyruvate dehydrogenase complex). A cause of congenital chronic lactic acidosis in infancy. Pediatr. Res. 11: $1198-1200$.

33. Robinson, B. H., J. Taylor, and S. Kahler. 1979. Combined $\alpha$-ketoacid dehydrogenase deficiency in the dehydrogenase complex of pyruvate, 2-oxoglutarate and the branched-chain ketoacids due to reduced activity of the third component enzyme ( $\mathrm{E}_{3}$ dihydrolipoyl dehydrogenase). In XIth International Congress of Biochemistry. Toronto, Ontario. Abstract 04-3-S70.

34. Rodriquez-Budelli, M., and R. A. P. Kark. 1978. Kinetic evidence of a structural abnormality of lipoamide dehydrogenase in two patients with Friedreich's ataxia. Neurology. 28: 1283-1286.

35. Kuroda, Y., J. J. Kline, L. Sweetman, W. L. Myhan, and T. D. Groshong. 1979. Abnormal pyruvate and $\alpha$ ketoglutarate dehydrogenase complexes in a patient with lactic acidemia. Pediatr. Res. 13: 928-931.

36. Robinson, B. H., and W. G. Sherwood. 1975. Pyruvate dehydrogenase phosphatase deficiency: a case of congenital chronic lactic acidosis in infancy. Pediatr. Res. 9: 935-939.

37. Koster, J. F., R. G. Slee, and J. Fernandes. 1978. Lactic acidosis due to a defect in the pyruvate dehydrogenase complex. A possible brain pyruvate dehydrogenase phosphatase deficiency. In Monographs in Human Genetics. O. Sperling and A. DeVries, editors. Karger, Basel. 9: 7-11.

38. Deviro, D. C., M. W. Haymond, K. A. Obert, J. S. Nelson, and A. S. Pagliara. 1979. Defective activation of pyruvate dehydrogenase complex in subacute necrotizing Encephalomyelopathy (Leigh's Disease). Ann. Neurol. 6: 483-494.

39. Utter, M. F., and K-F. R. Sheu. 1980. Biochemical mechanism of biotin and thiamin action and relationship to genetic disease. In Enzyme Therapy in Genetic Diseases. 2. R. J. Desnick, editor. Alan R. Liss, Inc., New York. 289-304.

40. Leiter, A. B., M. Weinberg, F. Isohashi, and M. F. Utter. 1978. Relationship between phosphorylation and activity of pyruvate dehydrogenase in rat liver mitochondria and the absence of such a relationship for pyruvate carboxylase. J. Biol. Chem. 253: 2716-2723.

41. Linn, T. C., J. W. Pelley, F. H. Pettit, F. Hucho, D. D. Randall, and L. J. Reed. 1972. $\alpha$-Keto acid dehydrogenase complex. XV. Purification and properties of the component enzymes of the pyruvate dehydrogenase complexes from bovine kidney and heart. Arch. Biochem. Biophys. 148: 327-342.

42. Siess, E. A., and O. H. Wieland. 1972. Purification and characterization of pyruvate dehydrogenase phosphatase from pig heart muscle. Eur. J. Biochem. 26: 96-105.

43. Dennis, S. C., M. DeButsere, R. Scholtz, and M. S. Olson. 1978. Studies on the relationship between ketogenesis and pyruvate oxidation in isolated rat liver mitochondria. J. Biol. Chem. 253: 2229-2237.

44. Lowry, O. H., N. J. Rosebrough, A. L. Farr, and R. J. Randall. 1951. Protein measurement with Folin phenol reagent. J. Biol. Chem. 193: 265-275.

45. Blass, J. P., R. A. P. Kark, and W. K. Engel. 1971. Clinical studies of a patient with pyruvate decarboxylase deficiency. Arch. Neurol. 25: 449-451.

46. Blass, J. P., J. D. Schulman, D. S. Young, and E. Ham. 
1972. An inherited defect affecting the tricarboxylic acid cycle in a patient with congenital lactic acidosis. J. Clin. Invest. 51: 1545-1551.

47. Whitehouse, S., and P. J. Randle. 1973. Activation of pyruvate dehydrogenase in perfused rat heart by dichloroacetate. Biochem. J. 134: 651-653.

48. Cederbaum, S. D., J. P. Blass, N. Minkoff, W. J. Brown, M. E. Cotton, and S. H. Harris. 1976. Sensitivity to carbohydrate in a patient with familiar intermittent lactic acidosis and pyruvate dehydrogenase deficiency.Pediatr. Res. 10: 713-720.

49. Blass, J. P., R. A. P. Kark, and N. K. Menon. 1976. Low activities of the pyruvate and oxoglutarate dehydrogenase complexes in five patients with Friedreich's ataxia. $N$. Engl. J. Med. 295: 62-67.

50. Haworth, J. C., T. L. Perry, J. P. Blass, S. Hansen, and N. Urguhart. 1976. Lactic acidosis in three sibs due to defects in both pyruvate dehydrogenase and $\alpha$-ketoglutarate dehydrogenase complexes. Pediatrics. 58: 564-572.

51. Wieland, O., E. Siess, H. J. V. Funcke, C. Patzelt, A. Schirmann, G. Loffler, and L. Weiss. 1971. Regulation of the mammalian pyruvate dehydrogenase complex: physiological aspects and characterization of PDH-phosphatase from pig heart. In Metabolic Interconversion of Enzymes. O. Wieland, E. Helmreich, and H. Holzer, editors. Springer-Verlag, Berlin. 293-309.

52. Siess, E. A., and O. H. Wieland. 1976. Phosphorylation state of cytosolic and mitochondrial adenine nucleotides and of pyruvate dehydrogenase in isolated rat liver cells. Biochem. J. 156: 91-102.

53. Portenhauser, R., and O. H. Wieland. 1977. Regulation of pyruvate dehydrogenase in heart mitochondria. HoppeSeyler's Z. Physiol. Chem. 385: 647-658.
54. Loffler, G., S. Bard, and O. H. Wieland. 1975. Control of pyruvate dehydrogenase interconversion of palmitoyl-coenzyme $A$ as related to adenine nucleotide translocation in isolated fat cell mitochondria. FEBS (Fed. Eur. Biochem. Soc.) Lett. 60: 269-273.

55. Ohlen, J., E. A. Siess, G. Loffler, and O. H. Wieland. 1978. The effect of insulin on pyruvate dehydrogenase interconversion in heart muscle of alloxan-diabetic rats. Diabetologia. 14: 135-139.

56. Stansble, D., R. Denton, B. J. Bridges, H. T. Pask, and P. J. Randle. 1976. Regulation of pyruvate dehydrogenase and pyruvate dehydrogenase phosphate phosphatase activity in rat epididymal fat-pads. Biochem. J. 154: 225-236.

57. Hutson, N. J., A. L. Kerbey, P. J. Randle, and P. H. Sugden. 1978. Conversion of inactive (phosphorylated) pyruvate dehydrogenase complex into active complex by the phosphatase reaction in heart mitochondria is inhibited by alloxan-diabetes or starvation in the rat. Biochem. J. 173: 669-680.

58. Reynolds, S. F., and J. P. Blass. 1976. A possible mechanism for selective cerebellar damage in partial pyruvate dehydrogenase deficiency. Neurology. 26: 625-628.

59. Kark, R. A. P., and M. Rodriguez-Budelli. 1979. Pyruvate dehydrogenase deficiency in spinocerebellar degenerations. Neurology. 29: 126-131.

60. Stumpf, D. A., and J. K. Park. 1979. Friedreich ataxia. II. Normal kinetics of lipoamide dehydrogenase. Neurology. 29: 820-826.

61. Lynen, A., E. Sedlaczek, and O. H. Wieland. 1978. Partial purification and characterization of a pyruvate dehydrogenase complex inactivating enzyme from rat liver. Biochem. J. 169: 321-328. 